\title{
CG 1305: AN OFFERING TABLE WITH A SHORT NOTATION ON FESTIVALS
}

\section{Dalia HANAFY*}

\begin{abstract}
:
This paper presents a round limestone offering table in the Egyptian Museum in Cairo (CG1305), which was recovered by A. Mariette during his excavations for the EAS, and is displayed in EMC-R 37. The offering table belongs to $K 3(. i)-h b$, dating to the Old Kingdom (Fourth Dynasty) and was discovered in Saqqara, mastaba C $27^{1}$ (Fig. No.1). The offering table bears a circular line of hieroglyphic writing in sunk relief around its upper edge; the text runs anticlockwise and contains a di nsw formula, the name of the deceased and his title.
\end{abstract}

Offering tables were important items of funerary equipment throughout ancient Egyptian history, and usually been found inside burial chambers. In the ancient Egyptian language a number of words are used to designate them, the most common being: htp, which appears in the texts of the Old Kingdom; ${ }^{2}\left[b 3\right.$, also from the Old Kingdom; ${ }^{3}$ and $h 3 w t^{4}$, the first attestation of which occurs in the tomb of $R^{e} h t p$ from the Fourth Dynasty at Maidum $^{5}$. The inscription on the present offering table reads as follows:

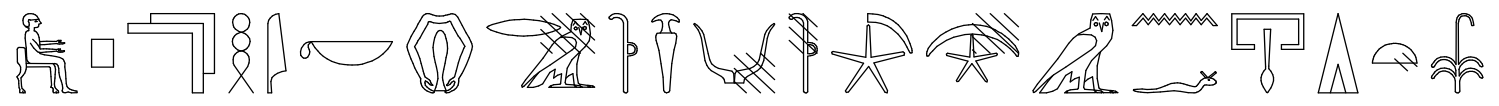

di nsw prt-hrw n.f $m$ 3bd smdt wp-rnpt tpi rnpt imy-r ḥm(.w)-k3 K3(.i)-hpšsp

\footnotetext{
${ }^{*}$ Department of History, Faculty of Arts, Mansoura University.

${ }^{1}$ Borchardt, L., Denkmäler des Alten Reiches I, Le caire, (1964), 5.

${ }^{2}$ Wb III, 183; Hannig, (1995), 567.

${ }^{3}$ Wb I, 177; Hannig, (1995), 135.

${ }^{4}$ Wb III, 226; Hannig, (1995), 580, and for more information, see Hölzl, R., Ägyptische Opfertafeln und Kultbecken, eine Form- und Funktionsanalyse für das Alte, Mittere und Neue Reich, Hildsheimer Ägyptologische Beiträge, Hildesheim, (2002); Mostafa, Maha M. F., Untersuchungen zu Opfertafeln im Alten Reich, Hildsheim, (1982); El-Khouli, A., Egyptian stonevessels: Predynastic Period to Dynasty III, 3 Bände, Mainz, (1978).

${ }^{5}$ Mostafa, Maha M. F., Untersuchungen zu Opfertafeln, 15
} 
"The king gives ${ }^{(a)}$ offerings $^{(b)}$ to him in the (festivals) of the month ${ }^{(\mathrm{c})}$, of the half-month ${ }^{(\mathrm{d})}$, beginning of the year ${ }^{(\mathrm{e})}$ and the head of the year (to) the overseer of the $K_{3}$ $\operatorname{priest}(\mathrm{s})^{(\mathrm{f})}$ Kaihap"(g). $^{(\mathrm{g})}$

(a) di $n s w$ (the King gives): the formula was abbreviated from htp di $n s w$ to di $n s w^{6}$.

(b) prt-hrw "verbal offerings"7. In most cases prt hrw is followed either by a stated event or place, rarely by both ${ }^{8}$; on our table prt hrw is followed by an event, i.e. festivals. In these cases prt hrrw is always followed by the preposition $m$, as in our case.

(c) $3 b d$ or $i b d$ "(the feast of) the month", "first of the month festival", "new crescent day" " " the festival of the beginning of the month" 11 or "the lunar day 2 "12.This monthly festival was celebrated on the first day of the lunar month, when the crescent was new in the sky ${ }^{13}$. Some scholars have suggested that these monthly feasts were celebrated on the second day of the lunar month on the basis that the day when the moon remained blacked out formed the first day of the Egyptian lunar year, the beginning of the month thus falling on the second day of the lunar month $^{14}$.

(d) $s m d t$ or (tp) smdt "(the feast of) the half-month" was the celebration of the full moon midway through the month. The feast is often translated as "fifteenth day feast"; the Wb translated it as "Fünfzehnten Tages des Mondmonats" i.e. "fifteenth day of the lunar month"15. According to Eaton this translation could be a sign that

\footnotetext{
${ }^{6}$ For more discussion of offering formula see Lapp, G., Die Opferformel des Alten Reiches, Deutsches Archäologisches Institut Abteilung Kairo, Sonderschrift 21, Mainz am Rhein, 1986; Barta, W., Aufbau und Bedeutung der ägyptischen Opferformel, Glückstadt, (1968).

${ }^{7}$ For the verbal and nominal offerings see Lapp, G., Die Opferformel des Alten Reiches, $139 \mathrm{f}$.

${ }^{8}$ Lapp, G., Die Opferformel des Alten Reiches, 102.

${ }^{9}$ Allen, J., PT, 84.

${ }^{10}$ Eaton, K.,"Monthly lunar festivals in the mortuary realm: Historical patterns and symbolic motifs", JNES 70/2 (2011), 242.

${ }^{11} \mathrm{~Wb}$ I 65, 8, 10.

${ }^{12}$ Depuydt, L., Civil calendar and lunar calendar in ancient Egypt, OLA 77, Leuven, (1997), 266.

${ }^{13}$ Eaton, K., JNES 70/2 (2011), 242.

${ }^{14}$ Eaton, K., JNES 70/2 (2011), 243; Spalinger, A. J., The private feast lists of Ancient Egypt, ÄA 57, Wiesbaden (1996), 2.

${ }^{15} \mathrm{~Wb}$ IV $, 147,1$.
} 
the feast of the half month was celebrated according to the civil year, rather than the lunar months ${ }^{16}$. Depuydt translated the word smdt as "lunar day $15^{17}$.

The festivals of the month and half month were amongst the most common of the day festivals in Ancient Egypt. They are attested in the feast lists from the Old Kingdom $^{18}$, in the Pyramid Texts (PT 324, 373, 438, 468, 483, 532, 610, 684, 690, 720-458, 726, ), in Coffin Texts (CT 6, 7, 72, 154, 156, 277, 253, 316, 318, $474,480,695,723,1013,1042,1151)$, and also in the Book of the Dead (BD 64 and 162$)^{19}$. They often appear at the end of the private feast lists ${ }^{20}$, and when the festival lists were abbreviated, they were usually ignored ${ }^{21}$. Sometimes both of them shared the determinative ${ }^{\varnothing}$; in our offering table, this determinative $\varnothing$ was omitted. Obviously, the two feasts were beneficial occasions on which offerings were made for the deceased. The benefits for the deceased in celebrating such festivals were rebirth, ascension, protection and not eating faces. According to Junker, such festival days were celebrated in the necropolis itself ${ }^{22}$.

(e) wp-rnpt "the beginning of the year or the opener of the year". The first day of the year is the opening of the year $(13 h t l)$ and according to Allen was celebrated as

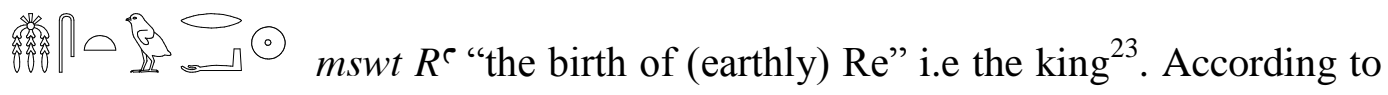
Parker wp rnpt was celebrated before the attestation of the civil year; he suggested that $w p r n p t$ was the first day of the lunar year ${ }^{24}$ and debated whether $w p$ rnpt is the heliacal rising of Sothis $s p d t^{25}$.

\footnotetext{
${ }^{16}$ Eaton, K., JNES 70/ 2 (2011), 243f.

${ }^{17}$ Depuydt, L., Civil calendar and lunar calendar in ancient Egypt, 27.

${ }^{18}$ For detailed information and a very useful discussion of these lists from the Old Kingdom see: Spalinger, A. J., The private feast lists of Ancient Egypt, Ägyptologische Abhandlungen 57, Wiesbaden, 1996, 2.

${ }^{19}$ Spalinger, A. J., The private feast lists of Ancient Egypt, 230.

${ }^{20}$ Spalinger, A. J., The Private feast lists of Ancient Egypt,; Depuydt, L., Civil calendar and lunar calendar in Ancient Egypt, Orientalia Lovaniensia Analecta 77, Leuven, 1997; Schott, S., Altägyptische Feastdaten, Abhandlungender Geistes- und sozialwissenchaftlichen Klasse, Wiesbaden, 1950.

${ }^{21}$ Schott, S., Altägyptische Feastdate., 230.

${ }^{22}$ Junker, H., Giza II,. 61.

${ }^{23}$ Allen, J. P., Middle Egyptian: An introduction to the language and culture of hieroglyphs, Cambridge, 2010, 107.

${ }^{24}$ Parker, R., The calendars of Ancient Egypt, Studies in Ancient Oriental Civilization 26, Chicago, 1950, $32 \mathrm{f}$.

${ }^{25}$ For more detailed discussion about wp rnpt see Parker, R., Calendars, 33 §164ff; Depuydt, Civil calendar and lunar calendar in ancient Egypt, 61-86.
} 
(f) imy-r hm $(w)-k 3$ "the overseer of Ka-servants" 26 . The title imy-r hm $(w) k 3$ appears several times at the Giza Necropolis, e.g. in the mastaba of Dag $\square$ and his family from the Fourth Dynasty ${ }^{27}$. Wash ptah $\triangle 8 \frac{8}{810}$, who probably lived at the end of the Fourth Dynasty or at the beginning of the Fifth Dynasty, ${ }^{28}$ bears the title "the overseer of Ka-servants" on the architrave of his tomb at Giza; he was perhaps "the overseer of Ka-servants" of Queen $h^{c} m r r ~ n b t i$, wife of King Cheops, since the queen's name appears on the same architrave ${ }^{29}$. From the Fourth Dynasty, the title is attested in the tomb of $k 3 i$, where he bears the title "the overseer of Ka-servants" ${ }^{30}$ for the princess $i 3 b t i t$; the title was written with the determinative $\square$ pr after imy-r $r^{31}$, which seems to be a rare variant, as Junker has pointed out ${ }^{32}$. The title cannot be read as 'the overseer of the house and the overseer of the ka-servants', because the word imy-r does not occur before $\mathrm{hm}$ $k$ 3. The title of "overseer of Ka-servants" also appears at the tomb of imbjj at Giza, who bears the title imy-r3hmm(.w) $k 3$ mwt $n s w$ "the overseer of the $K$ 3servants of the mother of the king". The same title is attested in the tomb of itti. The table below contains a list of officials at the Giza and Abu Rawash necropolis who bear the title imy-r hmm(.w) k3:

\footnotetext{
${ }^{26}$ Jones, D., "An index of Ancient Egyptian titles, epithets and phrases of the Old Kingdom", British Archaeology Reports 866, Oxford, 2000, 177, No. 673; Wb II, 90, 15; Urk I, 8, 14, Kees, H., "Die Phylen und ihren Vorsteher im Dienst der Tempel und Totenstiftungen (Untersuchungen zur Struktur der ägyptischen Priesterschaft im Alten und Mittleren Reich", Orientalia 17 (1948), 71.

${ }^{27} \mathrm{He}$ bears also the title $h m n t r$ of the King Cheops, Hassan, S., Excavationsat Giza 1930 - 1931, vol. 2, Cairo, 1936, 46, Kanawati, N., The Egyptian administration in the Old Kingdom, evidence on its economic decline, Warminster, 1977, 127, No. 378.

${ }^{28}$ Gillam, R. A., "Priestesses of Hathor: their function, decline and disappearance", JARCE 32 (1995), 219, No. 99.

${ }^{29}$ Hassan, S., Giza II, 10, Figs. 7,8; Helck, W., "Bemerkungen zu den Pyramidenstädten im Alten Reich”, MDAIK 15 (1975), P. 105; Gillam, R. A., JARCE 32 (1995), 219, 219, No. 99.

${ }^{30}$ The titles recur on the façade, on the entrance and on the western wall of the tomb see. Junker, H., Giza III, 129, Abb. 14, 131, Abb. 15.

${ }^{31}$ Junker, H., Grabungen auf dem Friedhof des Alten Reiches bei den Pyramiden von Giza, Bd. II: Die Mastabas der vorgeschrittenen Dynastie auf demWestfriedhof, Akadamie der Wissenschaften in Wien, Leipzig, 1938, 123 and P. 129, Abb. 14 and. 131, Abb. 15.

${ }^{32}$ Junker, H., Giza III, 141.
} 


\begin{tabular}{|c|c|c|}
\hline Tomb No. ${ }^{33}$ & The necropolis & $\begin{array}{c}\text { The name of the tomb } \\
\text { owner }\end{array}$ \\
\hline 81 & Giza & $W s r$ \\
\hline 152 & Giza & $n w 3 \underline{d} \underline{d}$ Pth\& nbišt \\
\hline 157 & Giza & $n m t . f$ \\
\hline 172 & Giza & $n f r^{34}$ \\
\hline 218 & Giza & hpj \\
\hline 269 & Abu Rawash & $\begin{array}{l}s 3 b n s w \text { (from the time of } \\
\text { King } \underline{d} d . f R^{\circ} \text { ) }\end{array}$ \\
\hline 318 & Giza & sdf 3 Pth \& Ffi \\
\hline 325 & Giza & $Q d f j j$ \\
\hline 354 & Giza & K3 hrst.f $f^{35}$ \\
\hline 335 & Giza & K3 pw nswt k3i \\
\hline
\end{tabular}

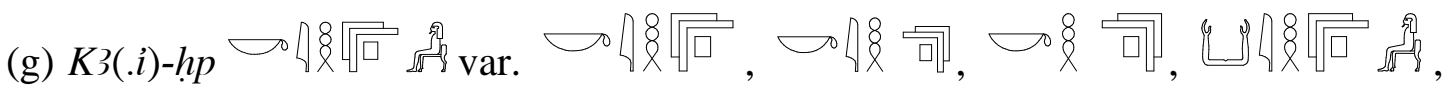

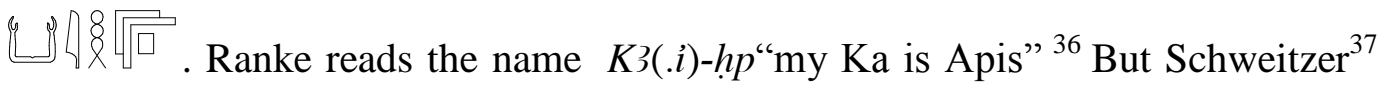
reads the name $K 3(. i)-h p . w$ "my Ka is Hapi". The name is attested in the tombs of Abu-Sir, Giza, Sheikh Said, Tehne and at Saqqara. The name appears in the tomb of ptah-htep on the southern wall, where there is a procession of 11 offeringbearers bringing joints of meat, birds and lotus flowers; the third and eighth persons in line bear the name $K 3(. i)-h p^{38}$. On the right jamb of a doorway at the

\footnotetext{
${ }^{33}$ These refer to the serial numbers of the tombs in Kanawati, N., The Egyptian administration in the Old Kingdom, evidence on its economic decline.

${ }^{34}$ This person bears also the title $h m n t r$ h hwfw, Kanawati, The Egyptian administration in the Old Kingdom, evidence on its economic decline, 101.

${ }^{35}$ This person bears the title imy-r\} $h m(. w) k 3 n h w t n s w$ "the overseer of the Ka-servants of the temple of the king", Kanawati, N., The Egyptian administration in the Old Kingdom, evidence on its economic decline, 123.

${ }^{36}$ Ranke, H., PN I, 340, No. 16.

${ }^{37}$ Schweitzer, S. K., Die Personennamen des Alten Reiches Altägyptische Onomastik unter lexikographischen und sozio-kulturellen Aspekten, Philippika Marburger altertumskundliche Abhandlungen 28, Wiesbaden, (2014), 705, No. 3493.

${ }^{38}$ Hassan, S., Mastabas of $\mathrm{Ny}^{-}{ }^{c}$ ankh-pepy and Others: Excavations at Saqqara, 1937-1938, vol. II, Cairo, (1975), 29.
} 
eastern end of the southern wall of the same tomb, three men are represented walking, and the second man also has the name $K 3(. i)-h p^{39}$. On a limestone stela founded in situ in the south chapel of Tomb No. 35 II north of Saqqara, and preserved now in the British Museum, the name $K 3(. i)$ - $h p$ occurs many times as a proper name for the owner of the stela ${ }^{40}$. The name also appears in the tomb of $d 3 g$ at the Giza Necropolis, in which one of his sons is called $K 3(. i)-h p$; the name occurs on the false door of the mother of $K 3(. \hat{i})-h p$, named as $\underline{t} t t y$, wife of $d 3 g^{41}$. A limestone false door in Berlin (ÄM 11469) ${ }^{42}$ bears the name on its architrave, alongside the name of King Weserkaf, first ruler of the Fifth Dynasty, on the right side of the false door. A limestone offering table in Berlin (ÄM 11467) ${ }^{43}$ likewise bears the name $K 3(. i)$ - hp, again alongside that of King Weserkaf, and it is clear that the false door and offering table belong to the same person, the owner of both items also bearing the title $h m n t r^{44}$. In addition, the name is attested in the tomb of Urarna wrirny in Sheikh Said, where one of his sons is named $K 3()).-h p^{45}$.

\section{Discussion}

It can be observed that the scribe who wrote the hieroglyphic signs on the offering table was inexperienced or unskilled. For instance, he began writing the signs at a large size from the phrase di nsw until wp rnpt, but then, observing that the remaining space was too small, had to reduce the scale of the signs until the end of the text. He also omitted the word im $3 h w$ before the name of the deceased, and it is quite clear that this was due to the space limitation. Furthermore, we have here an abbreviated festival list; this list includes the festivals of $3 b d$, smdt,wp rnpt and tp rnpt "the festivals of the month, of the half month, the beginning of the year and the head of the year". Notably, these festivals were amongst the most important in terms of the deceased, as they involved the giving of

\footnotetext{
${ }^{39}$ Hassan, S., Mastabas of $N y-{ }^{c}$ ankh-pepy and Others, 56.

${ }^{40}$ Martin, G. Th., The Tomb of Hetepka and other reliefs and inscriptions from the Sacred Animal Necropolis north Saqqara 1964-1973, Text from Excavations 4, London, (1979), 20, P1. 21, No. 14.

${ }^{41}$ Hassan, S., Giza II, Cairo, 1936, 55., Fig. 50.

${ }^{42}$ Schäfer, H., Ägyptische Inschriften aus den königlichen Museen zu Berlin, Bd. I: Inschriften von der ältesten Zeit bis zum Ende der Hyksoszeit, Leipzig, (1913), S. 44.

${ }^{43}$ Schäfer, H., Ägyptische Inschriften aus den königlichen Museen zu Berlin, 45.

${ }^{44}$ Schäfer, H., Ägyptische Inschriften aus den königlichen Museen zu Berlin, 45.

${ }^{45}$ Davies, N. De G., The Rock Tombs of Sheikh Said, Archaeological Survey of Egypt, London, (1901), Pl. 6, No. 25.
} 
offerings to the dead. According to Kees, such festivals reflect the desire of the deceased or tomb owner to be associated with his/her family members at specific festivals or religious holidays in the year ${ }^{46}$. Standard or complete festival lists from the Old Kingdom are attested in numerous private tombs at Giza and Saqqara, containing the following festivals names:
1- Wp rnpt
5- hbskr
9- $(3 b d n) s 3 \underline{d}$
2- $\underline{d} h w t y$
6- $h b w r$
10- $(t p) 3 b d$
3- tpy rnpt
7- $r k h$
11- (tp) smdt
4- w3gy
8- $\operatorname{prt} M n \quad 12-h \operatorname{bn} b\left(r^{c} n b\right)^{47}$

The arrangement or order of the festivals in the private lists was due to the importance of each individual celebration ${ }^{48}$. Based on the evidence listed above, I propose that the title imy $r 3 \mathrm{hm} \mathrm{k} 3$ was common in the time of the Fourth Dynasty and the beginning of the Fifth Dynasty. The title was connected directly with individuals who were involved in the cultic rites of the kings of these dynasties and their families. Similarly, the name $K 3(. i)-h p$ was prevalent during the Old Kingdom, especially from the Fourth to the early Sixth Dynasties, when most attestations of the name occur.

\footnotetext{
${ }^{46}$ Kees, H., Totenglauben und Jenseitsvorstellungen der alten Ägypter, Berlin, (1956), 120-121

${ }^{47}$ Spalinger, A. J., The private feast lists of Ancient Egypt, 110.

${ }^{48}$ Spalinger, A. J., The private feast lists of Ancient Egypt, 162.
} 


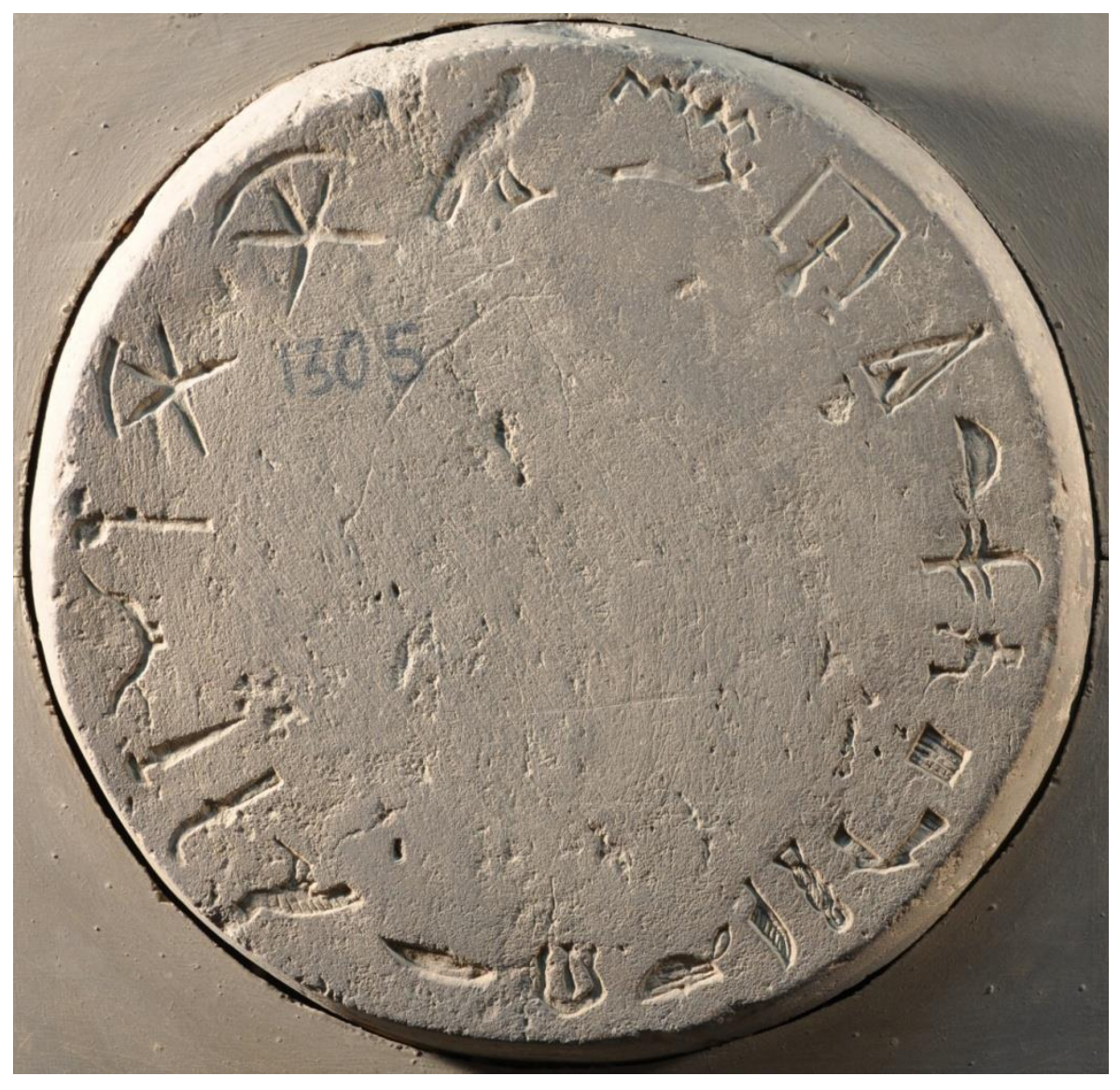

Fig. No. 1: CG 1305 


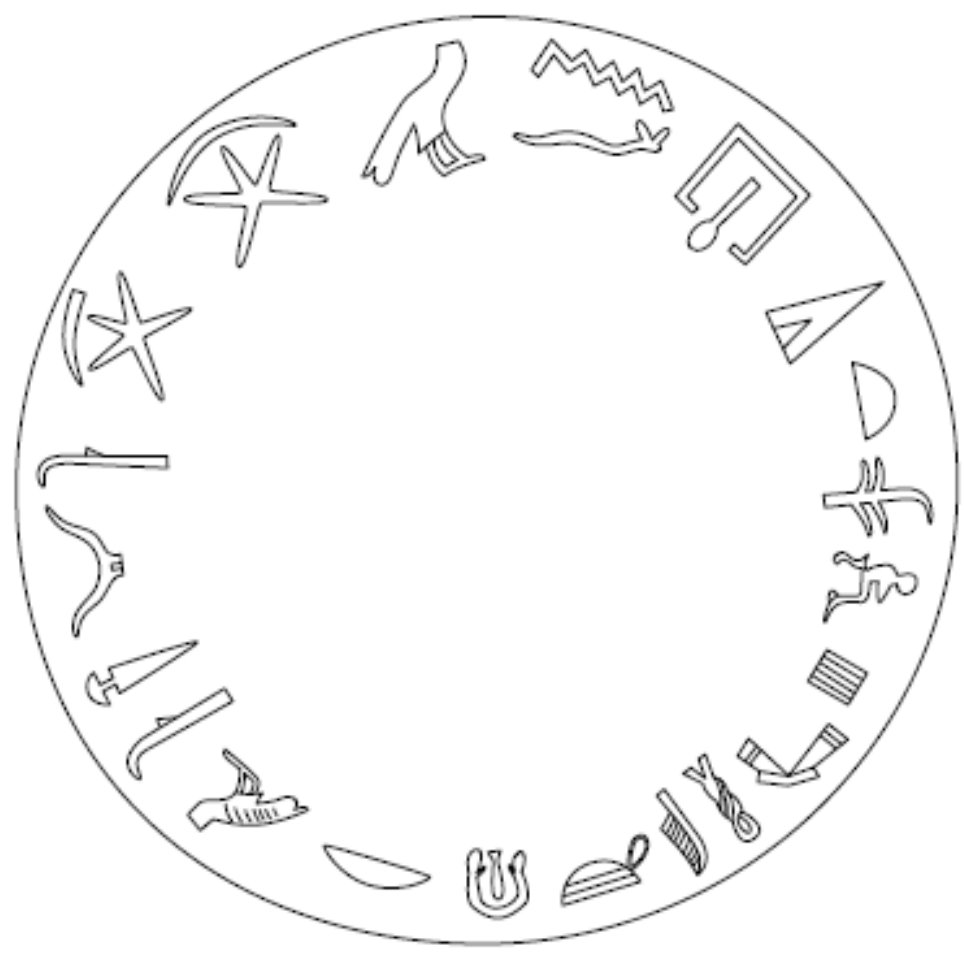

Facsimile : CG 1305 


\section{Bibliography:}

Allen, J. P., Middle Egyptian: An introduction to the language and culture of hieroglyphs, Cambridge, (2010).

Barta, W., Aufbau und Bedeutung der ägyptischen Opferformel, Glückstadt, (1968).

Davies, N. De G., The Rock Tombs of Sheikh Said, Archaeological Survey of Egypt, London, (1901).

Depuydt, L., "Civil calendar and lunar calendar in Ancient Egypt", Orientalia Lovaniensia Analecta 77, Leuven, (1997), 61-97

Eaton, K., "Monthly lunar festivals in the mortuary realm: Historical patterns and symbolic motifs", JNES 70/2 (2011), 229-245

El-Khouli, A., Egyptian stone vessels: Predynastic Period to Dynasty III, 3 Bände, Mainz, (1978).

Erman, A., \& Grapow, H., Wörterbuch der ägyptischen Sprache, 7vols, Berlin.

Gillam, R. A., "Priestesses of Hathor: their function, decline and disappearance", JARCE 32 (1995), 211-237

Hassan, S., Excavationsat Giza 1930 - 1931, vol. 2, Cairo, (1936).

Hassan, S., Mastabas of $\mathrm{Ny}^{\mathrm{c}}{ }^{\mathrm{a}}$ ankh-pepy and Others: Excavations at Saqqara, 1937-1938, vol. II, Cairo, (1975).

Helck, W., "Bemerkungen zu den Pyramidenstädten im Alten Reich”, MDAIK 15 (1975), 27-225

Hölzl, R., Ägyptische Opfertafeln und Kultbecken, eine Form- und Funktionsanalyse für das Alte, Mittere und Neue Reich, Hildsheimer Ägyptologische Beiträge, Hildesheim, 2002.

Jones, D., An index of Ancient Egyptian titles, epithets and phrases of the Old Kingdom, British Archaeology Reports 866, Oxford, (2000).

Junker, H., Grabungen auf dem Friedhof des Alten Reichesbei den Pyramiden von Giza, Bd. II: die Mastabas der vorgeschrittenen Dynastie auf dem Westfriedhof, Akadamie der Wissenschaften in Wien, Leipzig, (1938).

Kanawati, N., The Egyptian administration in the Old Kingdom, evidence on its economic decline, Warminster, (1977).

Kees, H., "Die Phylen und ihrenVorsteher im Dienst der Temple und Totenstiftungen (Untersuchungen zur Struktur der ägyptischen Priesterschaft im Alten und Mittleren Reich", Orientalia 17 (1948).

Kees, H.,Totenglauben und Jenseitsvorstellungen der alten Ägypter, Berlin, (1956).

Lapp, G., Die Opferformel des Alten Reiches, Deutsches Archäologisches InstitutAbteilung Kairo, Sonderschrift 21, Mainz am Rhein, (1986).

Martin, G. Th., The Tomb of Hetepka and other reliefs and inscriptions from the Sacred Animal Necropolis north Saqqara 1964-1973, Text from Excavations 4, London., (1979)

- 10 - CG 1305: An Offering Table 
Mostafa, Maha M. F.,Untersuchungen zu Opfertafeln im Alten Reich, Hildsheim, (1982).

Parker, R., The calendars of Ancient Egypt, Studies in Ancient Oriental Civilization 26, Chicago,(1950). Page number

Schäfer, H., Äegyptische Inschriftenaus den königlichen Museen zu Berlin, Bd. I: Inschriften von der ältesten Zeit bis zum Ende der Hyksoszeit, Leipzig, (1913).

Schott, S., Altägyptische feastdaten, Abhandlungen der Geisttes- und sozialwissenschaftlichen Klasse, Wiesbaden, (1950).

Schweitzer, S. K., Die Personennamen des Alten Reiches Altägyptische Onomastik unter lexikographischen und sozio-kulturellen Aspekten, Philippika Marburger altertumskundliche Abhandlungen 28, Wiesbaden, (2014).

Spalinger, A. J., Private feast lists of Ancient Egypt, Ägyptologische Abhandlungen 57, Wiesbaden, (1996). 